Gut, 1969, 10, 651-654

\title{
Colonic cancer and Crohn's disease
}

\author{
J. HYWEL JONES
}

From St Mark's Hospital, London

SUMMARY Four patients with both carcinoma and Crohn's disease of the colon are reported. Other cases in the world literature are summarized and the relationship between the two diseases is discussed. It is concluded that present evidence does not establish an increased risk of malignancy in colonic Crohn's disease.

The risk of malignant change in idiopathic proctocolitis is well established but there is no unequivocal evidence that Crohn's disease of the colon predisposes to carcinoma. In 1948 Warren and Sommers briefly reported an adenocarcinoma of the ascending colon in bowel affected by Crohn's disease but the association of the two conditions has attracted little attention until recent years. Interest has developed in conjunction with a growing awareness that proctocolitis and Crohn's disease confined to the colon are different diseases and that these two types of colitis can be distinguished on clinical, radiological, and pathological evidence (Lennard-Jones, Lockhart-Mummery, and Morson, 1968).

A review of the world literature has revealed reports of 11 patients in whom both carcinoma and Crohn's disease developed in the colon. Only six of these have been reported in any detail (Davis and Caley, 1960; Sheil, Clark, and Goligher, 1968; Parrish, Karsten, McRae, and Moretz, 1968; Perrett, Truelove, and Massarella, 1968). The paucity of the published data on the association of these two diseases has prompted this study of four further cases.

\section{CASE REPORTS}

These are summarized in Table $\mathrm{I}$.

\section{DISCUSSION}

Of the four patients reported here only two (cases 1 and 2) were admitted to St Mark's Hospital. The remaining two were referred from other hospitals for an opinion on the pathological nature of the lesions resected. The incidence of carcinoma has been two in 189 patients with Crohn's disease of the large intestine admitted to St Mark's Hospital.
Details of the reported cases with both colonic carcinoma and Crohn's disease, and the frequency of carcinoma in larger series, are summarized in Table II. It is evident that the incidence of malignancy in the published series of colonic Crohn's disease from different centres is low, with the exception of the Oxford series in which an incidence of $3.7 \%$ paralleled the incidence of $3.5 \%$ for carcinoma in patients with proctocolitis seen at the same hospital. Most of the patients reported have had a short history, the Crohn's disease and carcinoma presenting together. Only in two has the Crohn's disease long preceded the development of carcinoma.

The relationship between carcinoma and Crohn's disease in the small bowel may be different from that in the large bowel. There have been 17 case reports of carcinoma and Crohn's disease of the small intestine (Cantwell, Kettering, Carney, and Ludwig, 1968; Sheil et al, 1968; Morowitz, Block, and Kirsner, 1968). In these patients the Crohn's disease has usually been diagnosed many years before the carcinoma is discovered, and since Crohn's disease and carcinoma of the small bowel are both rare conditions, it is likely that the two are related.

Carcinoma of the large bowel is common and, therefore, its association with Crohn's disease is more difficult to evaluate. It may be that carcinoma is a complication of longstanding Crohn's disease of the colon but this complication is rare because this type of colitis has only recently been recognized and because many patients are treated by colectomy early in the course of the disease. Only 19 of our 189 patients with colonic Crohn's disease have preserved an intact colon for $\mathbf{1 0}$ or more years after the onset of their symptoms. Against this hypothesis is the fact that the histological picture of Crohn's disease is not that of a precarcinomatous condition because the main histological changes are found in 
TABLE I

PRESENT CASES OF CARCINOMA AND COLONIC CROHN'S DISEASE ${ }^{1}$

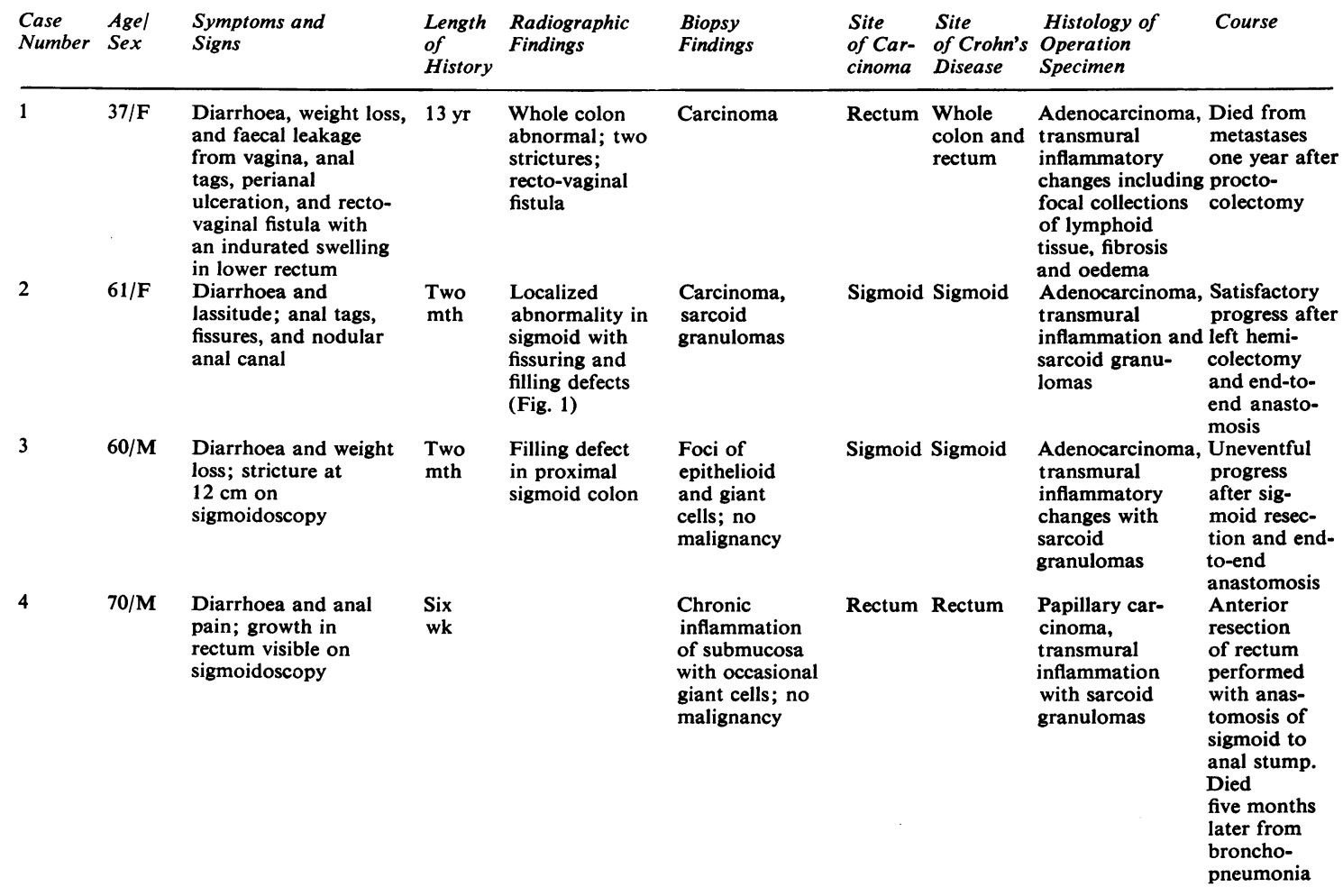

Cases 1 and 2 were admitted to St Mark's Hospital; cases 3 and 4 were referred to the hospital but not admitted and are, therefore, excluded from the St Mark's series of patients with colonic Crohn's disease.

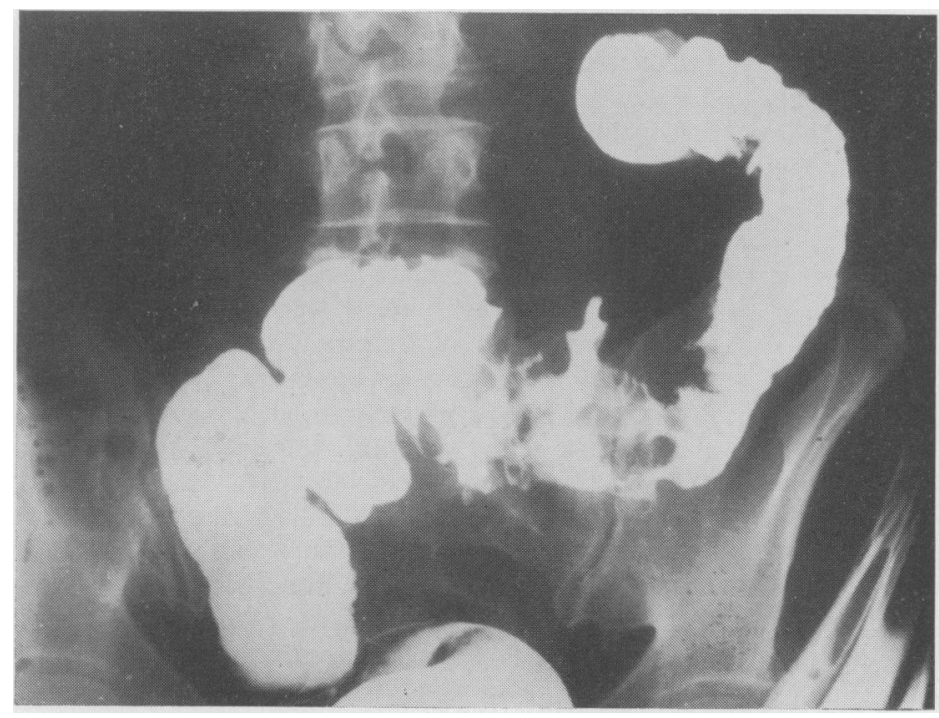

FIG. 1. Barium enema from case 2 showing a localized abnormality in the sigmoid colon with fissuring suggestive of Crohn's disease and filling defects suggestive of carcinoma. 
TABLE II

\section{REPORTED CASES OF CARCINOMA WITH COLONIC CROHN'S DISEASE}

\begin{tabular}{|c|c|c|c|c|c|c|c|}
\hline Author & Centre & $\begin{array}{l}\text { Incidence of } \\
\text { Carcinoma in } \\
\text { Colonic } \\
\text { Crohn's Disease }\end{array}$ & $\begin{array}{l}\text { Agel } \\
\text { Sex }\end{array}$ & $\begin{array}{l}\text { Length of } \\
\text { History }\end{array}$ & $\begin{array}{l}\text { Site of } \\
\text { Carcinoma }\end{array}$ & $\begin{array}{l}\text { Site of } \\
\text { Crohn's Disease } \\
\text { in the Colon }\end{array}$ & Comments \\
\hline $\begin{array}{l}\text { Warren and Sommers } \\
\text { (1948) }\end{array}$ & Boston, Mass & - & - & - & Ascending colon & Ascending colon & \\
\hline $\begin{array}{l}\text { Van Patter et al } \\
\text { (1954) }\end{array}$ & $\begin{array}{l}\text { Mayo Clinic, } \\
\text { Minnesota }\end{array}$ & 1 in 222 & 一 & - & - & - & No details given \\
\hline $\begin{array}{l}\text { Davis and Caley } \\
(1960)\end{array}$ & $\begin{array}{l}\text { Royal Infirmary, } \\
\text { Sheffield }\end{array}$ & - & $44 / F$ & $2 \frac{1}{2} \mathrm{yr}$ & $\begin{array}{l}\text { Pelvirectal } \\
\text { junction }\end{array}$ & Caecum & Isolated case \\
\hline $\begin{array}{l}\text { Cornes and Stecher } \\
\text { (1961) }\end{array}$ & $\begin{array}{l}\text { Gordon Hospital, } \\
\text { London }\end{array}$ & 0 in 45 & - & - & — & - & \\
\hline $\begin{array}{l}\text { Janowitz et al } \\
\text { (1965) }\end{array}$ & $\begin{array}{l}\text { Mount Sinai } \\
\text { Hospital, }\end{array}$ & 0 in 60 & 一 & - & & - & \\
\hline $\begin{array}{l}\text { Crohn and Yarnis } \\
\text { (1966) }\end{array}$ & New York & 2 in 291 & - & - & $\begin{array}{l}\text { Distal trans- } \\
\text { verse } \\
\text { colon }\end{array}$ & - & \\
\hline $\begin{array}{l}\text { Hawk and Turnbull } \\
\text { (1966) }\end{array}$ & $\begin{array}{l}\text { Cleveland } \\
\text { Clinic, Ohio }\end{array}$ & 1 in 87 & $75 / M$ & - & - & - & $\begin{array}{l}\text { Carcinoma and Crohn's } \\
\text { disease in different } \\
\text { parts of the colon }\end{array}$ \\
\hline $\begin{array}{l}\text { Sheil et al } \\
\text { (1968) }\end{array}$ & $\begin{array}{l}\text { General Infirmary, } \\
\text { Leeds }\end{array}$ & 1 in 106 & $50 / \mathrm{F}$ & $21 \mathrm{yr}$ & Rectum & $\begin{array}{l}\text { Whole colon } \\
\text { and rectum }\end{array}$ & $\begin{array}{l}\text { Carcinoma developed } \\
\text { after colectomy and } \\
\text { ileorectal anastomosis }\end{array}$ \\
\hline $\begin{array}{l}\text { Parrish et al } \\
\text { (1968) } \\
\text { McGovern and } \\
\text { Goulston (1968) }\end{array}$ & $\begin{array}{l}\text { Augusta, } \\
\text { Georgia } \\
\text { Royal Prince Alfred } \\
\text { Hospital, Sydney }\end{array}$ & 0 in 30 & $\begin{array}{l}65 / \mathrm{F} \\
-\end{array}$ & $\begin{array}{c}4 \mathrm{mth} \\
-\end{array}$ & $\begin{array}{l}\text { Caecum and } \\
\text { ascending colon } \\
-\end{array}$ & $\begin{array}{l}\text { Ascending and } \\
\text { transverse colon } \\
-\end{array}$ & Isolated case \\
\hline $\begin{array}{l}\text { Perrett et al } \\
\text { (1968) }\end{array}$ & $\begin{array}{l}\text { Radcliffe Infirmary, } \\
\text { Oxford }\end{array}$ & 3 in 82 & $\begin{array}{l}34 / F \\
67 / F\end{array}$ & $\begin{array}{l}2 \mathrm{mth} \\
2 \mathrm{mth}\end{array}$ & $\begin{array}{l}\text { Caecum } \\
\text { Sigmoid }\end{array}$ & $\begin{array}{l}\text { Caecum } \\
\text { Sigmoid }\end{array}$ & $\begin{array}{l}\text { Readmitted a year } \\
\text { later with Crohn's } \\
\text { disease of remaining } \\
\text { colon and carcinomas } \\
\text { of caecum and trans- } \\
\text { verse colon }\end{array}$ \\
\hline & & & $72 / \mathrm{F}$ & 3 wk & Caecum & $\begin{array}{l}\text { Caecum and } \\
\text { ascending colon }\end{array}$ & \\
\hline Present cases & $\begin{array}{l}\text { St Mark's } \\
\text { Hospital, London }\end{array}$ & 2 in 189 & \multicolumn{5}{|c|}{ Details in Table I } \\
\hline
\end{tabular}

the submucosa and the intestinal epithelium is relatively spared. The absence of precancerous epithelial changes in Crohn's disease contrasts with the findings in some cases of proctocolitis in which epithelial destruction is a prominent feature (Morson and Pang, 1967).

Conversely, it is possible that Crohn's disease is a complication of carcinoma. With this in mind, Sheil et al (1968) examined 12 cases of carcinoma of the small intestine in a search for histological evidence of Crohn's disease but found none. It is well known that sarcoid-like lesions can be found occasionally in the immediate neighbourhood of malignant neoplasms and in the regional lymph nodes (Gregorie, Othersen, and Moore, 1962). In all the cases reported here, however, the inflammatory lesion involved the bowel wall beyond the immediate confines of the tumour and showed in addition other stigmata of Crohn's disease such as cobblestoning, fissuring, and transmural inflammation.

Carconoma and Crohn's disease may develop in the same patient because of an individual predisposition to both diseases. This would account for the cases in which carcinoma and Crohn's disease have occurred in different parts of the intestine. A 56-year-old welder who had a resection for rectal carcinoma at this hospital was readmitted five years later because of Crohn's disease of the terminal ileum diagnosed at laparotomy. No evidence of Crohn's disease of the large intestine was found in the first operation specimen or at the second laparotomy. The occurrence of regional ileitis and rectal carcinoma in the same patient has been noted by other authors (Cornes and Stecher, 1961 ; LennardJones and Stalder, 1967) and cases in which Crohn's disease and carcinoma have developed in different areas of the large intestine have also been reported (Davis and Caley, 1960; Hawk and Turnbull, 1966).

Lastly, the association of carcinoma and Crohn's disease of the colon may be coincidental. Since 1949 a total of 3,910 patients with carcinoma of the large bowel, excluding carcinoma of the anus, have been admitted to this hospital. Among these, two have had colonic Crohn's disease compared with 44 patients who have had proctocolitis. These figures suggest that the risk of malignancy is perhaps much less in Crohn's disease than in proctocolitis but the 
relative incidence of Crohn's disease and proctocolitis is unknown. The incidence of Crohn's disease in this carcinomatous group cannot be compared with that of colonic Crohn's disease in the general population because this too is unknown.

Evidence to date suggests that the management of colonic Crohn's disease should not be influenced by fears of malignant change. In those patients with a short history the possibility of both Crohn's disease and carcinoma being present should be considered, remembering that a biopsy showing sarcoid granulomas does not exclude malignancy elsewhere.

I wish to thank Dr J. E. Lennard-Jones, Dr F. Avery Jones, Dr B. C. Morson, and Mr H. E. LockhartMummery for their valuable advice in the preparation of this paper. I am also grateful to Mr H. E. LockhartMummery, Sir Clifford Naunton Morgan, Mr J. L. Stephen (Paddington General Hospital), and Mr S. M. Power (Dreadnought Seamen's Hospital) for permission to publish the cases under their care. Mr N. Mackie kindly prepared the photograph.

\section{REFERENCES}

Cantwell, J. D., Kettering, R. F., Carney, J. A., and Ludwig, J. (1968) Adenocarcinoma complicating regional enteritis. Gastroentero$\log y, 54,599-604$.
Cornes, J. S., and Stecher, M. (1961). Primary Crohn's disease of the colon and rectum. Gut, 2, 189-201.

Crohn, B. B., and Yarnis, H. (1966). Granulomatous colitis: an attempt at clarification. J. Mt. Sinai Hosp., 33, 503-513.

Davis, A., and Caley, J. P. (1960). Crohn's disease with carcinoma of the colon. Postgrad. med. J., 36, 380-383.

Gregorie, H. B., Jr, Othersen, H. B., Jr, and Moore, M. P., Jr (1962). The significance of sarcoidlike lesions in association with malignant neoplasms. Amer. J. Surg., 104, 577-586.

Hawk, W. A., and Turnbull, R. B., Jr (1966). Primary ulcerative disease of the colon. Gastroenterology, 51, 802-805.

Janowitz, H. D., Lindner, A. E., and Marshak, R. H. (1965). Granulomatous colitis: Crohn's disease of the colon. J. Amer. med. Ass., 191, 825-828.

Lennard-Jones, J. E., Lockhart-Mummery, H. E., and Morson, B. C. (1968). Clinical and pathological differentiation of Crohn's disease and proctocolitis. Gastroenterology, 54, 1162-1170.

- and Stalder, G. A. (1967). Prognosis after resection of chronic regional ileitis. Gut, 8, 332-336.

McGovern, V. J., and Goulston, S. J. M. (1968). Crohn's disease of the colon. Gut, 9, 164-176.

Morowitz, D. A., Block, G. E., and Kirsner, J. B. (1968). Adenocarcinoma of the ileum complicating chronic regional enteritis. Gastroenterology, 55, 397-402.

Morson, B. C., and Pang, L. S. C. (1967). Rectal biopsy as an aid to cancer control in ulcerative colitis. Gut, 8, 423-434.

Parrish, R. A., Karsten, M. B., McRae, A. T., and Moretz, W. H. (1968). Segmental Crohn's colitis associated with adenocarcinoma. Am. J. Surg., 115, 371-375.

Perrett, A. D., Trulove, S. C., and Massarella, G. R. (1968). Crohn's disease and carcinoma of colon. Brit. med. J., 2, 466-468.

Sheil, F. O'M., Clark, C. G., and Goligher, J. C. (1968). Adenocar cinoma associated with Crohn's disease. Brit. J. Surg., 55, 53-58.

Warren, S., and Sommers, S. C. (1948). Cicatrizing enteritis (regional ileitis) as a pathologic entity. Amer. J. Path., 24, 475-501.

Van Patter, W. N., Bargen, J. A., Dockerty, M. B., Feldman, W. H., Mayo, C. W., and Waugh, J. M. (1954). Regional enteritis, Gastroenterology, 26, 347-450. 